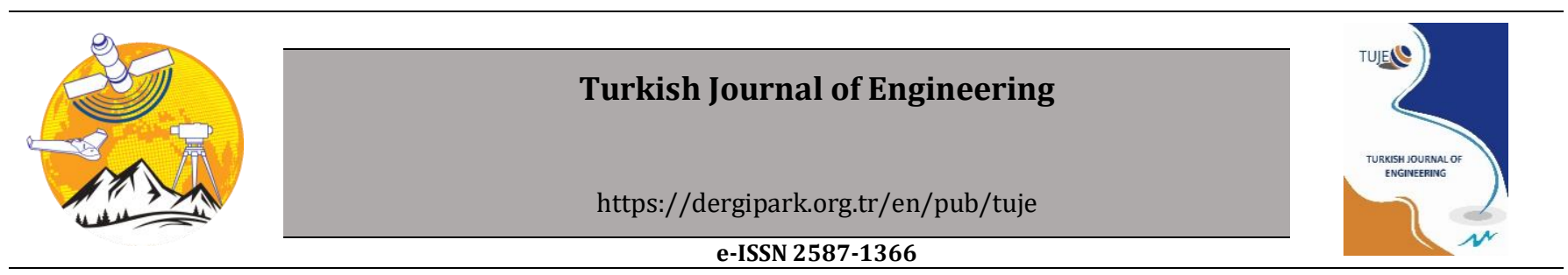

\title{
Integrated AHP-FMEA risk assessment method to stainless tank production process
}

\author{
Seçkin Çeliker ${ }^{1}$, Esra Saraç Eşsiz ${ }^{1}$ (D), Murat Oturakçi ${ }^{* 1}$ (D) \\ ${ }^{1}$ Adana Alparslan Türkeş Science and Technology University, Engineering Faculty, Industrial Engineering Department, Adana, Turkey
}

\section{Keywords}

Analytic hierarchy process

Failure mode and effect analysis

Risk priority number

Stainless tank

\begin{abstract}
This study aims to evaluate the hazards of the stainless tank production process in a company by using the Integrated Analytic Hierarchy Process (AHP) and Failure Mode and Effect Analysis (FMEA) methods. First, the hazards in the stainless tank production process were identified. Identified hazards were assessed with the FMEA method to calculate Risk Priority Number (RPN) for each hazard. The same hazards were then weighted by using the AHP method. Finally, AHP and FMEA are integrated to achieve a more objective result by using two subjective methods. According to the integrated method results, risks have been prioritized and an objective ranking has been established for action plans.
\end{abstract}

\section{INTRODUCTION}

Work accidents can be defined as unexpected events, often causing deaths, injuries, loss to machines and equipment, or stopping production for a certain period, which can often be counterworked if essential measures are taken. Occupational safety is defined as by creating healthy and safe working conditions in the work environment; minimizing work-related accidents and occupational diseases and thus increasing productivity by counterwork material and moral losses (Kurt 1993; Ceylan 2000).

Accidents at work in the world and Turkey have become a significant problem. Even though occupational accidents are a common issue of all countries; it can be reduced to a specific extent by taking essential measures. Countries failing to take these measures are more affected by accidents (https://ec.europa.eu/eurostat/data/database;https://i lostat.ilo.org/).

The most important conclusion of occupational accidents is the death, injury or disability of the employees. Besides, serious material losses are another important conclusion of occupational accidents. Even though it is a very serious improvement on the floor in occupational health and safety issues in Turkey, this should be done on the subject is also irrefragable that much is true. In recent years, the number of accidents per employee decreases. However, when the accident statistics of the last six years are analyzed, it is seen that there are 75840 occupational accidents per year in our country and 1103 employees lost their lives in these accidents. Besides, the material loss brought to our country by these accidents is estimated to be around 45 billion TL / year (Ceylan and Gül 2015)

The most important aim of our country's National Occupational Health and Safety policy is to reduce the frequency of occupational accidents. (Ceylan and Başhelvacı 2011; Korkmaz and Avsallı 2012). To achieve this goal, other than avoiding hazards, various studies should be performed to identify and evaluate risks in advance and to eliminate or minimize these risks.

The danger is defined as a situation that can cause great harm or extinction. The purpose of hazard identification is to identify the problems and levels that may arise from the workplace environment. Risk is the likelihood of a specific and unwanted event (danger) occurring within a certain period. The control of risks is to evaluate the measures to be taken within a certain hierarchy for each risk. Control and evaluation should be done to determine the priority order of the work to be performed. The goal in the control hierarchy should always be to eliminate danger and minimize the risk. Risk Assessment is the process of estimating the magnitude of risks arising from hazards in any system and deciding 
whether these risks are acceptable, taking into account the adequacy of existing controls (Ceylan and Başhelvacı 2011).

Song et al. (2007) applied the FMEA technique to quantitatively analyze the importance of each activity in terms of structural assembly and safety of steelworks. (Dey 2010), aims to develop an integrated framework for managing project risks by analyzing risk at a project, work package, and activity levels and developing reactions in this study. As a result of this study, AHP is an existing approach to achieve concurrency in controversial decisions. Wessiani and Sarwako (2015), applies fuzzy FMEA in his method taking into account the limitation of traditional FMEA in assessing the risk score by expert judgment, and these reform risks are classified according to RPFNs. Li and Zeng (2016) aim at the supplier selection method by applying failure modes and effect analysis (FMEA) to evaluate the risks in the decree process. In the literature, FMEA and AHP methods are encountered in different sectors and applications.

As seen in the literature, there are many studies where FMEA and AHP methods are applied. In this study, two subjective methods are integrated to make a more objective evaluation of the scores obtained by applying FMEA and AHP methods.

In this study, 17 risks were identified by observing the stainless tank production process in the factory. After identifying potential risks, the risk-threat table was first established. Risk Priority Scores (RPN) of risks were calculated using the FMEA method. Risks were also evaluated by the Analytical Hierarchical Process (AHP) method to calculate weights $\left(\mathrm{w}_{\mathrm{i}}\right)$ of hazards. Finally, the two methods were combined and the importance of the risks identified. In this way, it is aimed to reach a more objective result from two different subjective evaluations.

\section{MATERIALS AND METHODS}

\subsection{Materials}

This study was conducted in a company operating in the field of manufacturing and engineering that produces stainless tanks in Turkey.

Stainless tanks are mainly used in the food industry, industrial plants, hotels, and hotels to obtain potable water. Some design conditions must be determined before the stainless tank is manufactured. Depending on the criteria such as chemical properties, pressure, and temperature of the fluid to be stored in, they can be manufactured with or without walled stainless steel quality.

The stainless tank production process starts with CNC cutting. Rectangular metal sheets are cut by CNC machine to required measures. Then metal sheets are twisted by wreath machine to the desired shape. After CNC cutting, small protrusions are formed on the surface. These protrusions are eliminated during the grinding phase. Then, start to weld opening. One of the methods of steel joining is the application made to make the welding process more effective. After these processes are performed, tapping is performed to connect the two metals without requiring filling material. In the welding process, the end parts of the stainless tank after twisting are joined here and the main profile is formed. Finally, the stainless tank is washed together with special chemicals and it is made resistant to rust in the passivation process.

\subsection{Methods}

\subsubsection{Analytical hierarchy process (AHP)}

AHP method originally developed by Thomas Saaty as a Multi-Criteria Decision Making (MCDM) method (Saaty 1980). AHP can be described as a decision making and making method used in case the decision hierarchy can be described and gives percentage dispersion of decision points in terms of the factors affecting the decision. The steps to be taken to solve a decision-making problem related to AHP are as follows; First of all decision-making problem is identified. Then the interfactor comparison matrix is formed by using Table 1 . After that percentage of factors are determined. Finally, consistency in factor benchmarks is measured (Sivrikaya and Ünal 2018).

Table 1. AHP comparison table (Saaty 1980)

\begin{tabular}{ll}
\hline Rating & Description \\
\hline 1 & "Equal importance" \\
3 & "Moderate importance of one over another" \\
5 & "Strong importance of one over another" \\
7 & "Very strong importance of one over another" \\
9 & "Extreme importance of one over another" \\
$2,4,6,8$ & "Intermediate values" \\
\hline
\end{tabular}

\subsubsection{Failure mode and effects analysis (FMEA)}

FMEA is a conventional reliability and safety analysis technique that has indulged wide implementation of distinct products over several decades (Goddard 2000).

In general, possible errors are identified in the FMEA technique; the causes of each feasible error are identified, their effect on the customer is assessed, the controls that are applied are reviewed, regulative actions are committed and their application is monitored. Three parameters help determine error priorities. These are the effect of severity (S), error probability (P) and detectability (D).

In its most general form, the method can be summed up in five main steps. First of all the method is started with early studies. Then, suitable error types, causes, effects, and current controls are used to identify the error. Risk Priority Numbers are calculated by determining the effect of severity $(\mathrm{S})$, probability $(\mathrm{P})$, detectability (D). Risk Priority Numbers are calculated by multiplying the effect of severity $(\mathrm{S})$, error probability $(\mathrm{P})$ and detectability (D). After that, sorting according to the risk priority number and determining the errors and actions to be taken. Finally, the determined activities are implemented and the new risk priority number is calculated (Yllmaz 2000; Aran 2006). Severity, probability and detectability values are presented in Tables 2, 3 and 4 respectively. After calculation of the RPN score, hazards are evaluated according to Table 5. 
Table 2. Severity table (Xu et al. 2002)

\begin{tabular}{|c|c|c|}
\hline Effect & Effect of Severity (S) & Degree \\
\hline Warning & $\begin{array}{l}\text { The potential error that can cause } \\
\text { catastrophe }\end{array}$ & 10 \\
\hline Warning & $\begin{array}{l}\text { Failure of warning and failure, which can } \\
\text { lead to high damage and mass deaths }\end{array}$ & 9 \\
\hline Too High & $\begin{array}{l}\text { Failure of warning and failure, which } \\
\text { can lead to high damage and mass } \\
\text { deaths }\end{array}$ & 8 \\
\hline High & $\begin{array}{l}\text { It causes complete damage to the } \\
\text { equipment and has the effect of death, } \\
\text { poisoning, 3rd-degree burn, acute fatal } \\
\text { disease, etc. }\end{array}$ & 7 \\
\hline Middle & $\begin{array}{l}\text { Affecting the performance of the } \\
\text { system, causing loss of limb and organ, } \\
\text { severe injury, cancer, etc. }\end{array}$ & 6 \\
\hline Low & $\begin{array}{l}\text { Fracture, permanent minor disability, } \\
\text { 2nd-degree burns, brain concussion, } \\
\text { etc. }\end{array}$ & 5 \\
\hline Very Low & $\begin{array}{l}\text { Error causing short-term discomfort } \\
\text { with minor injuries such as being } \\
\text { injured, minor cuts and abrasions, } \\
\text { crushes, etc. }\end{array}$ & 4 \\
\hline Small & Error slowing down system operation & 3 \\
\hline Very Small & Error slowing down system operation & 2 \\
\hline No & No effect & 1 \\
\hline
\end{tabular}

Table 3. Probability table (Xu et al. 2002)

\begin{tabular}{lccc}
\hline Effect & \multicolumn{2}{c}{ Error Probability } & Degree \\
\cline { 2 - 4 } $\begin{array}{l}\text { Too high: } \\
\text { Unavoidable }\end{array}$ & $1 / 3$ & $33,33 \%$ & 10 \\
Error & $1 / 8$ & $12,50 \%$ & 8 \\
\hline $\begin{array}{l}\text { High: Error } \\
\text { Repeatedly }\end{array}$ & $1 / 20$ & $5,00 \%$ & 7 \\
\cline { 2 - 4 } & $1 / 80$ & $1,25 \%$ & 6 \\
\hline $\begin{array}{l}\text { Moderate: } \\
\text { Occasional Error }\end{array}$ & $1 / 200$ & $0,50 \%$ & 5 \\
\cline { 2 - 4 } & $1 / 2.000$ & $0,05 \%$ & 4 \\
\hline Low: Relatively & $1 / 15.000$ & $0,006 \%$ & 3 \\
\cline { 2 - 4 } Few Errors & $\begin{array}{c}\text { Lower than } \\
1 / 1.500 .000\end{array}$ & $0,0006 \%$ & 2 \\
\hline Few: Unlikely & - & 1 \\
\hline Error & & & \\
\hline
\end{tabular}

Table 4. Detectability table (Xu et al. 2002)

\begin{tabular}{|c|c|c|}
\hline Effect & Effect of Detectability (D) & Degree \\
\hline Unnoticeable & $\begin{array}{l}\text { It is not possible to discover } \\
\text { the cause of the potential error }\end{array}$ & 10 \\
\hline Very little & $\begin{array}{l}\text { It is too far to discover the } \\
\text { cause of the potential error }\end{array}$ & 9 \\
\hline Little & $\begin{array}{l}\text { It is far to discover the cause of } \\
\text { the potential error }\end{array}$ & 8 \\
\hline Very low & $\begin{array}{l}\text { Low potential to detect the } \\
\text { cause of the potential error }\end{array}$ & 7 \\
\hline Low & $\begin{array}{l}\text { The cause of the potential } \\
\text { error is too low to discover }\end{array}$ & 6 \\
\hline Middle & $\begin{array}{l}\text { The cause of the potential } \\
\text { error can be discovered the } \\
\text { medium }\end{array}$ & 5 \\
\hline High Average & $\begin{array}{l}\text { The high average for } \\
\text { discovering the cause of the } \\
\text { potential error }\end{array}$ & 4 \\
\hline High & $\begin{array}{l}\text { High potential to detect the } \\
\text { cause of the potential error }\end{array}$ & 3 \\
\hline Very High & $\begin{array}{l}\text { The cause of the potential } \\
\text { error is too high to be } \\
\text { discovered }\end{array}$ & 2 \\
\hline $\begin{array}{l}\text { Almost } \\
\text { Certain }\end{array}$ & $\begin{array}{l}\text { It is almost certain that the } \\
\text { cause of the potential error } \\
\text { can be discovered }\end{array}$ & 1 \\
\hline
\end{tabular}

Table 5. RPN scale (Xu et al. 2002)

\begin{tabular}{ll}
\hline RPN & FMEA-Measure \\
\hline RPN $<40$ & No need to take precautions \\
$40 \leq$ RPN $\leq 100$ & It is useful to take precautions \\
$100<$ RPN & Precautions must be taken \\
\hline
\end{tabular}

\section{RESULTS AND DISCUSSIONS}

In this part, the hazards that can be encountered in the stainless tank production process of a company serving in the complete design, manufacturing, engineering and assembly works of the industrial plants have been determined with observations and expert opinions. Obtained hazard definitions are presented in Table 6.

Table 6. Hazard definitions

\begin{tabular}{|c|c|}
\hline $\begin{array}{l}\text { Hazard } \\
\text { No\# }\end{array}$ & Definition of Hazard \\
\hline 1 & $\begin{array}{l}\text { Oxygen cylinders used in the factory are close to the } \\
\text { welding machine and the spiral machine, which can } \\
\text { cause an explosion. }\end{array}$ \\
\hline 2 & $\begin{array}{l}\text { The tubes may explode as the worker uses electronic } \\
\text { cigarettes near oxygen cylinders. }\end{array}$ \\
\hline 3 & $\begin{array}{l}\text { Due to the overhead crane on the CNC machine, the } \\
\text { operator can be hit and injured by careless handling. }\end{array}$ \\
\hline 4 & $\begin{array}{l}\text { Workers may have an occupational accident as they are } \\
\text { tired and careless due to their busy working tempo. }\end{array}$ \\
\hline 5 & $\begin{array}{l}\text { machine after cutting on the CNC machine, the operator } \\
\text { and workers can get caught in the parts and fall and be } \\
\text { injured. }\end{array}$ \\
\hline 6 & $\begin{array}{l}\text { As a result of insufficient lighting in the production area } \\
\text { of the factory, workers may have accidents and injuries. }\end{array}$ \\
\hline 7 & $\begin{array}{l}\text { Due to the length of the cables of some hand tools used, } \\
\text { the parts may fall and workers may be injured. }\end{array}$ \\
\hline 8 & $\begin{array}{l}\text { Due to broken parts of the wooden support where some } \\
\text { heavy metal parts are placed, the parts may fall and } \\
\text { cause injury. }\end{array}$ \\
\hline 9 & $\begin{array}{l}\text { As the rope used for lifting and transporting heavy parts } \\
\text { is worn out, the part may fall during lifting or } \\
\text { transportation and cause injury or death. }\end{array}$ \\
\hline 10 & $\begin{array}{l}\text { The operator may be injured if the filter on the CNC } \\
\text { machine falls. }\end{array}$ \\
\hline 11 & $\begin{array}{l}\text { Since the dust pot does not have a lid, overfilled metal } \\
\text { parts can be injured by the employees passing by the } \\
\text { ladle. }\end{array}$ \\
\hline 12 & $\begin{array}{l}\text { Workers may fall and get injured due to loosening in } \\
\text { some parts of the metal step around the twisting } \\
\text { machine }\end{array}$ \\
\hline 13 & $\begin{array}{l}\text { As workers enter the tank during welding, it may result } \\
\text { in death if the employee or the tank falls. }\end{array}$ \\
\hline 14 & Workers may be injured as a result of broken hand tools. \\
\hline 15 & $\begin{array}{l}\text { Employees may fall and get injured due to the } \\
\text { inadequate metal step which is used for welding or } \\
\text { entering the tank. }\end{array}$ \\
\hline 16 & $\begin{array}{l}\text { Failure to perform regular morning checks of the trucks } \\
\text { may damage the vehicle. }\end{array}$ \\
\hline 17 & Accidents can occur due to the narrow internal road. \\
\hline
\end{tabular}

The hazards identified during the stainless tank production process were evaluated by the FMEA method. During the assessment, the effect of severity, the probability of error and the probability of detectability were taken into consideration. Table 2 , Table 3 and Table 4 were used for each component. After determining the required values, RPN was calculated for each hazard. As a result of the RPN calculation, the hazards are ranked according to their RPN score and presented in Table 7. 
Table 7. FMEA application results

\begin{tabular}{llll}
\hline $\begin{array}{l}\text { Hazard } \\
\text { No \# }\end{array}$ & $\begin{array}{l}\text { RPN } \\
\text { Score }\end{array}$ & Priority & Interpretation \\
\hline 16 & 240 & 1 & Precautions must be taken \\
13 & 216 & 2 & Precautions must be taken \\
4 & 162 & 3 & Precautions must be taken \\
14 & 140 & 4 & Precautions must be taken \\
3 & 70 & 5 & It is useful to take precautions \\
15 & 60 & 6 & It is useful to take precautions \\
5 & 48 & 7 & It is useful to take precautions \\
10 & 45 & 8 & It is useful to take precautions \\
6 & 40 & 9 & It is useful to take precautions \\
17 & 30 & 10 & No need to take precautions \\
1 & 27 & 11 & No need to take precautions \\
9 & 25 & 12 & No need to take precautions \\
12 & 24 & 13 & No need to take precautions \\
8 & 21 & 14 & No need to take precautions \\
11 & 20 & 15 & No need to take precautions \\
2 & 18 & 16 & No need to take precautions \\
7 & 9 & 17 & No need to take precautions \\
\hline
\end{tabular}

According to this ranking, Hazard \#16 has the highest RPN score and Hazard \#13, Hazard \#4, Hazard \#14 is calculated as the top risks as well while Hazard \#9 has the lowest RPN score.

As the second application step of the study hazards is identified in the stainless tank production process has been prioritized by using the AHP method. A CR (Consistency Ratio) of less than 0.10 indicates that the comparisons made by the decision-maker are consistent. As a result of the dual evaluation of the hazards which are in the stainless tank production process, the weight score for each hazard is calculated and presented in Table 8. Table 1 was used for this evaluation.

Table 8. AHP application results

\begin{tabular}{lll}
\hline Hazard No \# & Wi & Priority Order \\
\hline 13 & 0,1931 & 1 \\
12 & 0,1599 & 2 \\
8 & 0,1298 & 3 \\
9 & 0,1140 & 4 \\
15 & 0,0821 & 5 \\
1 & 0,0634 & 6 \\
16 & 0,0499 & 7 \\
2 & 0,0470 & 8 \\
5 & 0,0314 & 9 \\
3 & 0,0283 & 10 \\
6 & 0,0235 & 11 \\
11 & 0,0188 & 12 \\
17 & 0,0168 & 13 \\
7 & 0,0128 & 14 \\
4 & 0,0116 & 15 \\
14 & 0,0093 & 16 \\
10 & 0,0074 & 17 \\
\hline
\end{tabular}

According to these weights, the hazards are prioritized within themselves. This order of priority is given in Table 8. According to these results, while Hazard \#13 has the highest weight, Hazard \#10 has the lowest weight. When both results are compared, differences in prioritization occur. For instance, the top 5 hazards which have the highest RPN value are different from the top 5 hazards which have the highest weight.
The values given when determining the RPN and Weight score of hazards may vary according to the opinion of the expert performing the risk analysis. If the expert is indecisive, or if he or she evaluates even one parameter differently when analyzing by another expert, the risk score or weight may be calculated differently. As a result of different calculations, a hazard that needs to be taken into the action plans can be ignored.

Even though measurements in FMEA and comparisons in AHP are performed by the same expert team in the company; results vary from each other which illustrates the subjectivity of the methods which confuses about which hazard should be taken into consideration. Hence, a combination of these two methods has been performed to decrease the subjectivity level, to prevent the negative effects of these subjective evaluations and a more objective result has been tried to be obtained. As a result of AHP-FMEA integration, RPN * $W i$ scores of risks in the stainless tank production process were determined and presented in Table 9.

Table 9. Integrated AHP-FMEA application results

\begin{tabular}{lll}
\hline Hazard No \# & Wi*RPN & Priority Order \\
\hline 13 & 41,7260 & 1 \\
16 & 11,9821 & 2 \\
15 & 4,9297 & 3 \\
12 & 3,8383 & 4 \\
9 & 2,8518 & 5 \\
8 & 2,7260 & 6 \\
3 & 1,9817 & 7 \\
4 & 1,8919 & 8 \\
1 & 1,7122 & 9 \\
5 & 1,5092 & 10 \\
14 & 1,3135 & 11 \\
6 & 0,9424 & 12 \\
2 & 0,8472 & 13 \\
7 & 0,1160 & 14 \\
17 & 0,5062 & 15 \\
11 & 0,3765 & 16 \\
10 & 0,3358 & 17 \\
\hline
\end{tabular}

When hazards are prioritized according to integrated AHP - FMEA risk assessment results, Pareto analysis has been applied to the results to identify which hazards should be taken into action plans primarily. The Pareto chart for integrated results is presented in Figure 1. According to the results, the company needs to focus on Hazard \#13, Hazard \#16, Hazard \#15, Hazard \#12, Hazard \#9 because of the 80-20 rule of Pareto.

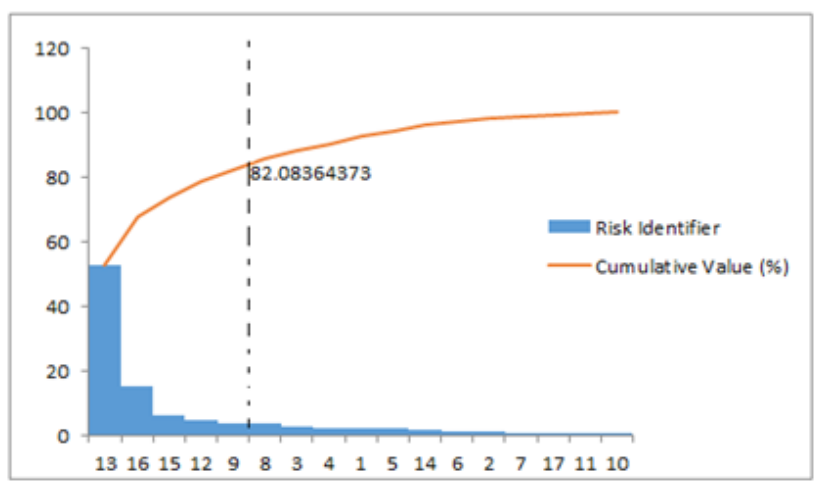

Figure 1. Pareto chart for integrated results 


\section{CONCLUSION}

The use of risk assessment methods performed in companies within the framework of Occupational Health and Safety differs in sectors. The differences between the results of the methods; In risk analyzes performed at decision points where experts are inadequate or hesitant when applying the methods, the results of incorrect prioritization of hazards and incorrect classification of related hazards appear.

In this study, an integrated risk assessment method for the stainless tank production process is performed. FMEA, AHP, and AHP-FMEA integration methods are applied and results are compared for the selected process. In this study, first, 17 hazards were identified in the stainless tank production process. To assess these risks, the FMEA method was applied. The severity, probability, and detectability of the risk were considered when FMEA was implemented. The Risk Priority Number (RPN) was calculated for each risk after FMEA was administered. Then the risks were weighted by applying AHP. The AHP-FMEA integration method was applied to avoid differences in the aforementioned results and to obtain more objective results.

\section{REFERENCES}

Aran G (2006). In Quality improving process failure mode effect and an application. MS Thesis, Gaziosmanpaşa Üniversity, Turkey (in Turkish).

Ceylan H \& Başhelvacı V S (2011). Risk değerlendirme tablosu yöntemi ile risk analizi: bir uygulama. International Journal of Engineering Research and Development, 3(2), 25-33 (in Turkish).

Ceylan H \& Gül T S (2015). Facts on safety at work for Turkey. Journal of Multidisciplinary Engineering Science and Technology, 2(5), 1192-1200.

Ceylan H (2000). A model called "deviation from weighted means for forecasting occupational accidents in production systems. PhD Thesis, Gazi Üniversity, Turkey (in Turkish).

Dey P K (2010). Managing project risk using combined analytic hierarchy process and risk map. Applied Soft Computing, 10(4), 990-1000. DOI: 10.1016/j.asoc.2010.03.010
Eurostat, Statistics European Statistics on Accidents At Work

https://ec.europa.eu/eurostat/data/database

[Accessed date: 06.03.2020]

Goddard P L (2000). Software FMEA techniques. Annual Reliability and Maintainability Symposium. Los Angeles, USA, 118-123. DOI: 10.1109/RAMS.2000.816294.

ILO (International Labor Office), https://ilostat.ilo.org/ [Accessed date: 06.03.2020]

Korkmaz A \& Avsallı H (2012). A New Stage in Work Life: Work Health and Safety Law No. 6331. Süleyman Demirel University Journal of Social Sciences, (26), 153-167 (in Turkish).

Kurt M (1993). İş Kazalarının Ergonomik Analizi. PhD Thesis, Gazi University, Turkey (in Turkish).

Li S \& Zeng W (2016). Risk analysis for the supplier selection problem using failure modes and effects analysis (FMEA). Journal of Intelligent Manufacturing, 27, 1309-1321. DOI: 10.1007/s10845-014-0953-0

Saaty T L (1980). The analytical hierarchy process, planning, priority. Resource allocation. RWS publications, USA.

Sivrikaya B T \& Ünal E (2018). Competency based performance evaluation of it employees by AHP group decision making. International Journal of Economics and Administrative Studies, 501-514.

Song J W, Yu J H \& Kim C D (2007). Construction safety management using FMEA technique: Focusing on the cases of steel frame work. 23rd Annual ARCOM Conference, Belfast, UK, 55-63.

Wessiani N A \& Sarwoko S O (2015). Risk analysis of poultry feed production using fuzzy FMEA. Procedia Manufacturing, $\quad 4, \quad 270-281$ DOI: 10.1016/j.promfg.2015.11.041

Xu K, Tang L C, Xie M, Ho S L \& Zhu M L (2002). Fuzzy assessment of FMEA for engine systems. Reliability Engineering \& System Safety, 75(1), 17-29. DOI: 10.1016/S0951-8320(01)00101-6

Yılmaz B S (2000). Hata Türü ve Etkileri Analizi, Dokuz Eylül Üniversitesi Sosyal Bilimler Enstitüsü Dergisi, 2(4), 133-150 (in Turkish). 